\title{
Kajian Kelayakan Teknologi Usahatani Jagung di Kabupaten Kendal, Jawa Tengah

\author{
Feasibility Study of Maize Farm Technology \\ in Kendal District, Central Java
}

\author{
Dewi Sahara, Elly Kurniyati, Renie Oelviani, dan Sodiq Jauhari \\ Balai Pengkajian Teknologi Pertanian (BPTP) Jawa Tengah \\ Jalan Soekarno-Hatta Km. 26 No. 10 Bergas, Kab. Semarang Jawa Tengah \\ E-mail : dewisahara.ds@gmail.com
}

Diterima: 21 Februari 2020

Revisi: 9 Juni 2020

Disetujui: 12 Agustus 2020

\begin{abstract}
ABSTRAK
Kebutuhan jagung nasional mengalami peningkatan yang signifikan, namun kebutuhan tersebut belum mampu diimbangi dengan peningkatan produksi, sehingga perlu upaya perbaikan teknologi usahatani. Penelitian bertujuan untuk mengetahui kelayakan usahatani jagung, mengetahui kelayakan usahatani akibat perubahan teknologi usahatani jagung dan nisbah peningkatan keuntungan dari perubahan teknologi, serta mengetahui titik impas produksi dan titik impas harga. Kegiatan dilaksanakan di Desa Wirosari, Kecamatan Patean, Kabupaten Kendal pada Mei-September 2018. Metode penelitian dengan demplot teknologi usahatani benih jagung seluas 1 ha dan pengamatan pada usahatani jagung konsumsi seluas $1 \mathrm{ha}$. Hasil penelitian menunjukkan bahwa produksi usahatani benih jagung sebanyak $1.550 \mathrm{~kg} / \mathrm{ha}$ dan benih afkir $663 \mathrm{~kg} / \mathrm{ha}$, sedangkan usahatani jagung konsumsi menghasilkan produksi $6.300 \mathrm{~kg} / \mathrm{ha}$. Dengan harga benih Rp35.000,00/kg dan harga jagung konsumsi Rp4.000,00/kg maka keuntungan usahatani benih jagung Rp39.911.000,00/ha ( $B C R=2,35$ ) dan keuntungan usahatani jagung konsumsi Rp14.523.000,00/ha $(B C R=1,36)$. Untuk memproduksi benih jagung petani menambah biaya sebesar Rp6.314.000,00 namun mendapatkan tambahan keuntungan Rp25.388.000,00/ha dengan nisbah keuntungan bersih 2,75 persen. Toleransi penurunan produksi dan harga adalah 69,10 persen untuk usahatani benih jagung dan 57,63 persen untuk usahatani jagung konsumsi. Oleh karena itu untuk meningkatkan produksi dan keuntungan petani jagung perlu adanya perluasan percontohan teknologi perbenihan jagung di beberapa sentra produksi jagung.
\end{abstract}

kata kunci: teknologi usahatani, benih jagung, jagung konsumsi

\section{ABSTRACT}

National maize needs have increased significantly, but these needs have not been offset by increased production, so it needs efforts to improve farming technology. This study aimed to know the feasibility of maize farming, the feasibility of maize farming due to technological change and the increased profit ratio, and the break-even point of production and price. The study was conducted in Wirosari Village, Patean Sub-District, Kendal District, in Mei-September 2018. The study methodology used 1 ha demonstration plot of maize seed technology and 1 ha observation of consumption maize farming technology. The result showed that maize seed farming production of $1,550 \mathrm{~kg} / \mathrm{ha}$ and reject seed $663 \mathrm{~kg} / \mathrm{ha}$, while consumption maize farming production of $6.300 \mathrm{~kg} / \mathrm{ha}$. The seed price IDR35,000.00/kg and consumption maize price IDR4,000.00/kg so profit from maize seed farming was IDR 39,911,000.00/ha $(B C R=2.35)$ and profit from consumption maize farming was IDR 14,523,000.00/ha $(B C R=1.36)$. The maize seed farming needed additional cost IDR 6,314,000.00 but provide an additional profit of IDR 25,388,000 with a net profit ratio of 2.75 percent. The tolerance of decrease in production and prices in maize seed farming was 69.10 percent, and in consumption, maize farming was 57.63 percent. Therefore to increase the production and profit of maize farmers, it is necessary to expand pilot maize seed technology in several maize production centers.

keywords: farming technology, maize seed, consumption maize

\section{PENDAHULUAN}

Jagung merupakan salah satu komoditas pangan utama setelah padi. Selain dapat dimanfaatkan sebagai pangan pengganti beras, jagung juga berfungsi sebagai bahan baku industri pangan, bahan baku industri pakan, dan bahan bakar. Dalam beberapa tahun terakhir peningkatan kebutuhan jagung belum dapat 
diimbangi dengan peningkatan produksi jagung dalam negeri, sehingga Pemerintah masih melakukan impor, meskipun dengan jumlah impor yang menurun (Nugroho, 2015).

Produksi jagung nasional pada tahun 2018 sebesar 30.056 .000 ton dengan produktivitas 5,24 ton/ha, meskipun konsumsi rumah tangga menurun, namun konsumsi jagung untuk industri non pakan meningkat 6,37 persen/tahun dan pakan langsung mengalami peningkatan ratarata 2,31 persen/tahun (Pusdatin, 2018). Amzeri (2018) memperkirakan lebih dari 55 persen produksi jagung nasional digunakan untuk pakan, 30 persen untuk pangan dan industri pangan, sedangkan 15 persen lainnya untuk kebutuhan industri lainnya dan untuk benih. Tingginya permintaan jagung untuk pakan disebabkan berkembangnya industri peternakan ayam ras.

Jawa Tengah sebagai sentra jagung terbesar kedua setelah Jawa Barat dengan kontribusi 11,36 persen dari produksi nasional dan ratarata peningkatan produktivitas selama 10 tahun terakhir sebesar 2,49 persen/tahun (BPS Jawa Tengah, 2019). Peningkatan produktivitas yang dicapai masih di bawah peningkatan permintaan jagung. Oleh karena itu perlu upaya untuk meningkatkan produktivitas jagung di Jawa Tengah.

Peningkatan produksi jagung dapat dimulai dengan penanaman benih unggul berpotensi hasil tinggi (Wahyudin, dkk., 2017; Sari, dkk., 2018). Namun yang menjadi masalah adalah ketersediaan benih unggul jagung belum banyak tersedia hingga ke tingkat petani. Sebagaimana dikatakan oleh Handoko dan Mulyadi (2017) bahwa benih unggul jagung atau benih bersertifikat yang sampai ke petani masih rendah, yaitu sekitar 40-50 persen dari kebutuhan benih petani. Oleh karena itu petani menggunakan benih lokal atau benih yang diperoleh dari hasil panen sebelumnya. Kondisi ini menyebabkan produktivitas yang diperoleh semakin lama semakin rendah karena benih mengalami degradasi secara genetik (Sejati, 2015).

Kajian kelayakan teknologi usahatani jagung baik jagung untuk benih maupun jagung untuk konsumsi dilakukan untuk mempermudah akses petani dalam rangka menyediakan benih jagung. Penelitian bertujuan untuk mengetahui kelayakan teknologi usahatani jagung, mengetahui kelayakan usahatani akibat perubahan teknologi usahatani jagung dan nisbah peningkatan keuntungan dari perubahan teknologi, serta mengetahui titik impas produksi dan titik impas harga.

\section{METODOLOGI}

\subsection{Lokasi dan Waktu Penelitian}

Penelitian dilaksanakan di Desa Wirosari, Kecamatan Patean, Kabupaten Kendal pada Mei-September 2018. Desa Wirosari merupakan daerah dataran rendah dengan ketinggian 525 m dpl berada pada koordinat $7^{\circ} 06^{\prime} 22.2^{\prime \prime}$ Lintang Selatan dan $110^{\circ} 04^{\prime 2} 21.2$ " Bujur Timur. Pemilihan lokasi penelitian dilakukan atas dasar pertimbangan Kabupaten Kendal merupakan salah satu wilayah pengembangan jagung di Jawa Tengah dengan tingkat produksi 6,88 ton/ ha.

\subsection{Benih}

Benih yang digunakan untuk memproduksi benih jagung hibrida Bima 20 URI adalah benih induk tetua jantan galur NEI-9008 dan benih induk tetua betina varietas Bima 4 yang berasal dari Balai Penelitian Tanaman Serealia Maros, Sulawesi Selatan.

\subsection{Metode Pelaksanaan Penelitian}

Penelitian dirancang dengan menggunakan pendekatan on farm research dalam bentuk percontohan (demplot) di lahan petani seluas 1 ha dan pengamatan usahatani jagung konsumsi pada lahan petani seluas 1 ha. Perbedaan usahatani jagung untuk benih dan usahatani jagung untuk konsumsi terletak pada penggunaan benih. Usahatani jagung untuk benih menggunakan benih tetua jantan dan benih tetua betina dengan komposisi induk jantan dan betina adalah 1:4. Untuk memproduksi benih jagung maka benih tetua jantan ditanam terlebih dahulu di lahan yang telah disiapkan. Setelah 3-4 hari tetua jantan ditanam diikuti dengan penanaman benih tetua betina. Adapun komponen teknologi usahatani benih jagung dan teknologi usahatani jagung konsumsi disajikan pada Tabel 1. 
Tabel 1. Komponen Teknologi Usahatani Benih Jagung dan Jagung Konsumsi di Desa Wirosari, Kecamatan Patean, Kabupaten Kendal, 2018

\begin{tabular}{|c|c|c|c|}
\hline \multirow{2}{*}{ No. } & \multirow{2}{*}{ Komponen Teknologi } & \multicolumn{2}{|c|}{ Jenis Teknologi Usahatani } \\
\hline & & Benih Jagung & Jagung Konsumsi \\
\hline \multirow[t]{3}{*}{1.} & Varietas benih & & Bisi 18 \\
\hline & a. Tetua jantan & Galur NEI.9008 & - \\
\hline & b. Tetua betina & Bima-4 & - \\
\hline \multirow[t]{3}{*}{2.} & Jumlah benih (kg/ha) & - & 15 \\
\hline & a. Tetua jantan & 7 & - \\
\hline & b. Tetua betina & 12 & - \\
\hline 3. & Perlakuan benih & Melataxil & - \\
\hline 4. & Jumlah benih per lubang & 2 biji/lubang & 2 biji/lubang \\
\hline 5. & Pengolahan tanah & TOT & Sederhana \\
\hline 6. & Jarak tanam & $70 \times 40 \mathrm{~cm}$ & $70 \times 20 \mathrm{~cm}$ \\
\hline \multirow[t]{6}{*}{7.} & Pupuk (kg/ha) : & & \\
\hline & a. Urea & 350 & 365 \\
\hline & b. SP-36 & 150 & 110 \\
\hline & c. $\mathrm{KCl}$ & - & 60 \\
\hline & d. Phonska & 400 & 165 \\
\hline & e. Pupuk organik & 2.000 & 1.600 \\
\hline 8. & Roguing/seleksi & $\begin{array}{l}\text { Pada stadia awal pertumbuhan, } \\
\text { fase vegetatif, fase berbunga, } \\
\text { setelah berbunga dan } \\
\text { menjelang panen. }\end{array}$ & - \\
\hline 9. & Detaselling & $\begin{array}{l}\text { 52-63 hst, semua tetua betina } \\
\text { sebelum keluar rambut jagung } \\
\text { dan benang sari pecah }\end{array}$ & - \\
\hline 10. & Pengendalian OPT & Pengendalian terpadu & Kimiawi \\
\hline 11. & Panen dan pasca panen & $\begin{array}{l}\text { - Panen manual } \\
\text { - Pemipilan manual } \\
\text { - Pengeringan dengan } \\
\text { penjemuran }\end{array}$ & $\begin{array}{l}\text { - Panen manual } \\
\text { - Pemipilan manual } \\
\text { - Pengeringan dengan } \\
\text { penjemuran }\end{array}$ \\
\hline
\end{tabular}

Sumber: Data primer, 2018 (diolah)

Implementasi teknologi usahatani benih jagung adalah sebagai berikut : (i) pengolahan lahan dengan mengaplikasikan pupuk organik (kompos yang berasa dari kotoran sapi) sebanyak 2 ton/ha; (ii) membuat bedengan bidang olah dengan ukuran $10 \mathrm{~m} \times 100 \mathrm{~m}$ sehingga dalam luasan 1 ha terdapat 10 petak bidang olah; (iii) benih diberi perlakuan dengan bahan aktif Melataksil dengan dosis $7 \mathrm{~g}$ per kilogram benih; (iv) penanaman benih jagung dilakukan dengan cara menugal dengan jarak tanam $70 \mathrm{~cm} \times 40 \mathrm{~cm}$ dengan jumlah benih 2 biji/lubang. Selanjutnya lubang tanam ditutup menggunakan pupuk kandang secukupnya; (v) pemupukan I dilakukan setelah 7-10 HST menggunakan pupuk Urea dengan dosis $200 \mathrm{~kg} /$ ha dan pupuk Ponska $250 \mathrm{~kg} / \mathrm{ha}$; (vi) pemupukan II dilakukan pada umur 35 HST menggunakan pupuk Urea dengan dosis $150 \mathrm{~kg} / \mathrm{ha}$ dan pupuk Ponska 150 kg/ha; (vii) penyiangan dilakukan minimal 2 kali tergantung kondisi gulma; (viii) pengendalian OPT menggunakan konsep PHT dengan cara memadukan pengendalian OPT secara terintegrasi dengan pendekatan ekologi, yaitu pendekatan kultur teknis dengan menanam benih yang tahan penyakit, eradikasi tanaman yang terserang OPT dan perlakuan kimiawi dengan menggunakan aplikasi pestisida sesuai rekomendasi; (ix) roughing/seleksi, yaitu membuang rumpun-rumpun tanaman 
yang menyimpang dari ciri marfologis tanaman yang benihnya diproduksi, dimulai dari stadia vegetatif serta generatif tanaman; $(x)$ detaseling yaitu membuang bunga tanaman pada tanaman betina sebelum bunga malai mekar (benangsari pecah); dan (xi) panen dilakukan jika jagung telah menunjukkan masak fisiologis ditandai dengan adanya lapisan hitam (black layer) antara tongkol dan biji, batang, daun, kelobot dan rambut jagung mengering. Indikator tersebut dicapai pada umur \pm 100 HST. Pada setiap tanaman diambil 4 tongkol secara acak dan dibiarkan di lapangan agar kadar air 28-29 persen. Selanjutnya jagung dipipil dan dijemur hingga kadar air 9-10 persen. Benih yang diperoleh dikemas dalam kantong plastik putih buram dengan ketebalan $0,2 \mathrm{~mm}$.

\subsection{Metode Analisis Data}

Untuk menjawab tujuan yang telah ditetapkan, analisis menggunakan metode with and without (teknologi usahatani benih jagung dan teknologi usahatani jagung konsumsi).

Pertama, untuk mengetahui kelayakan ekonomi teknologi usahatani jagung setiap teknologi dianalisis dengan analisis finansial disadur sebagaimana digunakan oleh Silva dan Murdolelono (2011); Kurniati (2012); Suharno dan Rusdin (2017) sebagai berikut :

$$
\begin{aligned}
& T R=\sum(P y . Y) \\
& T C=\sum\left(P x_{i} \cdot X_{i}\right) \\
& \pi=T R-T C \\
& B / C=\pi / T C
\end{aligned}
$$

\section{Keterangan:}

$$
\begin{aligned}
\mathrm{TR} & =\text { Total revenue/penerimaan (Rp/ha) } \\
\mathrm{Py} & =\text { Harga jagung (Rp/kg pipilan kering) } \\
\mathrm{Y} & =\text { Jumlah jagung (kg pipilan kering) } \\
\mathrm{TC} & =\text { Total cost/biaya (Rp/ha) } \\
\mathrm{Px}_{\mathrm{i}} & =\text { Harga input produksi ke-i } \\
\pi & =\text { Keuntungan usahatani jagung (Rp/ha) } \\
\mathrm{X}_{\mathrm{i}} & =\text { Input produksi ke-i } \\
\mathrm{B} / \mathrm{C} & =\text { Kelayakan usahatani. }
\end{aligned}
$$

Apabila $\mathrm{B} / \mathrm{C}>1$ berarti teknologi usahatani jagung efisien dan, jika $B / C<1$ berarti teknologi usahatani jagung belum efisien dan tidak menguntungkan, tetapi jika $\mathrm{B} / \mathrm{C}=$ 1 artinya teknologi usahatani jagung berada pada titik impas, yaitu tidak rugi dan juga tidak menguntungkan (Apriani, dkk., 2016).

Kedua, untuk mengetahui tingkat kelayakan usahatani akibat perubahan teknologi menggunakan analisis losses and gains melalui keuntungan dan biaya marginal atau Marginal Benefit and Cost Ratio (MBCR) dengan rumus :

$M B C R=\frac{\pi_{\text {benih }}-\pi_{\text {konsumsi }}}{T C_{\text {benih }}-T C_{\text {konsumsi }}}$

Apabila nilai $\mathrm{MBCR}=1$ berarti teknologi usahatani benih jagung tidak memberikan peningkatan pendapatan, atau tambahan pendapatan sama dengan tambahan biaya, bila MBCR $<1$ berarti tambahan pendapatan dari teknologi usahatani benih jagung lebih kecil daripada tambahan biaya, dan bila MBCR > 1 maka tambahan pendapatan dari teknologi usahatani benih jagung lebih besar daripada tambahan biaya (Margaretha dan Syuryawati, 2017).

Ketiga, untuk melihat perbandingan keragaan tingkat keuntungan usahatani dengan sistem tanam yang berbeda diukur dengan Nisbah Peningkatan Keuntungan Bersih (NKB) dengan rumus Rusdin dkk. (2012); Hidayat dkk. (2012) sebagai berikut :

$N K B=\frac{\pi_{\text {benih }}}{\pi_{\text {konsumsi }}}$

Keterangan:

$\mathrm{NKB}=$ Nilai keuntungan bersih

$\pi_{\text {benih }}=$ Keuntungan usahatani benih jagung

$\pi_{\text {konsumsi }}=$ Keuntungan usahatani jagung konsumsi

Empat, untuk mengetahui produksi minimum dan mentolerir penurunan produksi atau harga produk sampai batas tertentu dimana teknologi tersebut masih memberikan keuntungan yang normal dianalisis dengan analisis titik impas. Titik impas produksi (TIP) dan titik impas harga $(\mathrm{TIH})$ dihitung dengan rumus sebagai berikut :

$T I P=T C / P y$

$T I H=T C / Y$

(Kurniati, 2012; Dewi, dkk., 2015; Handoko dan Adri, 2016). 


\section{HASIL DAN PEMBAHASAN}

\subsection{Kelayakan Teknologi Usahatani Jagung}

\subsubsection{Penerapan Teknologi Usahatani Jagung}

Penerapan teknologi usahatani jagung di tingkat petani dapat diidentifikasi dari penggunaan input produksi. Pada teknologi usahatani jagung baik teknologi perbenihan maupun teknologi jagung konsumsi petani menggunakan benih, pupuk, pestisida dan tenaga kerja. Perbedaan prinsip pada kedua jenis teknologi tersebut adalah penggunaan benih jagung tetua jantan dan tetua betina untuk teknologi perbenihan, sedangkan teknologi produksi jagung konsumsi petani menggunakan benih jagung varietas Bisi 18 yang diperoleh dari kios pertanian di lokasi kegiatan. Perbedaan jenis dan jumlah input produksi pada teknologi usahatani jagung di Kabupaten Kendal disajikan pada Tabel 2.
Pada teknologi usahatani benih jagung menggunakan benih tetua jantan dari Galur NEl.9008 sebanyak $6 \mathrm{~kg} / \mathrm{ha}$ dan benih tetua betina Bima-4 sebanyak $12 \mathrm{~kg} / \mathrm{ha}$, sehingga benih yang dgunakan sebanyak $18 \mathrm{~kg} / \mathrm{ha}$. Benih tetua tersebut diperoleh dari Balai Penelitian Tanaman Serealia Maros, Sulawesi Selatan. Penggunaan benih ini hampir sama dengan perbenihan jagung di Kabupaten Sigi, Sulawesi Tengah, yaitu benih FS varietas Provit $A$ dan Provit B masing-masing sebanyak $20 \mathrm{~kg} / \mathrm{ha}$ (Dewi, dkk., 2015).

Berbeda dengan teknologi usahatani benih jagung, usahatani jagung konsumsi ratarata menggunakan benih jagung Varietas Bisi 18 sebanyak 13,5 kg/ha. Varietas tersebut disukai petani karena berproduksi tinggi, tahan terhadap penyakit bulai dan kekeringan, serta hasil produksi mudah dijual dengan harga tinggi. Penggunaan benih oleh petani di lokasi kegiatan masih tergolong rendah dibandingkan dengan

Tabel 2. Rata-rata Penggunaan Input Produksi per Hektare Teknologi Usahatani Jagung di Desa Wirosari, Kecamatan Patean, Kabupaten Kendal, 2018

\begin{tabular}{llrr}
\hline \multirow{2}{*}{ No. Jenis Input Produksi } & \multicolumn{2}{c}{ Jenis Teknologi Usahatani } \\
\cline { 2 - 4 } 1. & Benih (kg) & Benih Jagung & Jagung Konsumsi \\
a. Tetua jantan & 12 & 13,5 \\
b. Tetua betina & & - \\
2. Pupuk (kg) : & 350 & 365 \\
a. Urea & - & 110 \\
b. SP-36 & - & 60 \\
c. KCl & 400 & 165 \\
d. Phonska & 2.000 & 1.600 \\
e. Organic & & \\
Tenaga kerja (HOK) : & 28 & 14 \\
a. Pengolahan tanah & 20 & 13 \\
b. Perlakuan benih dan tanam & 8 & 8 \\
c. Penyulaman & 16 & - \\
d. Rouging/seleksi & 42 & - \\
e. Detaselling & 13 & 12 \\
f. Pemupukan & 9 & 5 \\
g. Pengendalian OPT & 18 & 13 \\
h. Penyiangan & 14 & 14 \\
i. Panen & 22 & 21 \\
j. Pemipilan & 18 & 14 \\
k. Pengeringan & 208 & 114 \\
Jumlah tenaga kerja & & \\
\hline
\end{tabular}

Sumber: Data primer, 2018 (diolah) 
penggunaan benih di Kabupaten Boyolali, yaitu $15,14 \mathrm{~kg} / \mathrm{ha}$ (Wahyuningsih, dkk., 2018) dan belum sesuai dengan rekomendasi rata-rata penggunaan benih, yaitu $20 \mathrm{~kg} / \mathrm{ha}$ (Purwanto, dkk., 2015). Belum sesuainya penggunaan benih dapat disebabkan jarak tanam yang digunakan dan kondisi kesuburan lahan yang berbeda.

Kedua jenis teknologi usahatani jagung menggunakan pupuk yang bervariasi baik jenis maupun jumlahnya. Pada teknologi usahatani benih jagung, penggunaan pupuk disesuaikan dengan rekomendasi pemupukan untuk tanaman jagung, yaitu Pupuk Urea sebanyak 350 kg/ha, Phonska $400 \mathrm{~kg} / \mathrm{ha}$ dan pupuk organik (kompos) sebanyak $2.000 \mathrm{~kg} / \mathrm{ha}$, sedangkan teknologi usahatani jagung konsumsi menggunakan pupuk Urea, SP-36, KCl dan Phonska serta pupuk Petroganik dengan dosis yang bervariasi.

Meskipun pupuk yang diberikan petani beragam, namun petani mengharapkan dengan memberikan pupuk pada tanaman jagung dapat meningkatkan produksi. Seperti yang dikemukakan oleh Pusparini, dkk. (2018) bahwa tanaman jagung memerlukan unsur hara $\mathrm{N}, \mathrm{P}$ dan $\mathrm{K}$ pada fase vegetatif dan fase generatif. Unsur $\mathrm{N}$ berperan untuk pembentukan karbohidrat, protein, lemak dan persenyawaan organik lain, sedangkan unsur $P$ digunakan untuk membentuk bagian generatif tanaman, dan unsur $\mathrm{K}$ digunakan untuk memacu translokasi karbohidrat dari daun ke organ tanaman lainnya. Pemberian pupuk secara lengkap memberikan hasil lebih tinggi dibandingkan dengan tanpa memberikan salah satu unsur hara N, P atau K (Syafruddin, 2016; Damanhuri, dkk., 2018).

Tenaga kerja pada usahatani benih jagung maupun jagung konsumsi digunakan untuk kegiatan persiapan tanam, tanam, pemeliharaan, panen dan pasca panen. Rata-rata tenaga kerja yang digunakan untuk usahatani benih jagung sebanyak 208 HOK, sedangkan untuk usahatani jagung konsumsi sebanyak 114 HOK. Penggunaan tenaga kerja ini lebih sedikit dibandingkan penggunaan tenaga kerja untuk produksi jagung konsumsi di Kabupaten Bone Sulawesi Selatan yang diusahakan di lahan sawah, yaitu sebanyak 306 HOK (Tahir, 2017). Penelitian Sulistiani (2015) di Kabupaten Malang mendapatkan hasil penggunaan tenaga kerja pada usahatani jagung berkisar antara 295-397 HKSP (Hari Kerja Setara Pria). Perbedaan ini dapat disebabkan adanya perbedaan jumlah input produksi yang digunakan dan perbedaan kondisi lahan pertanaman.

Terdapat perbedaan 94 HOK antara usahatani benih jagung dengan usahatani jagung konsumsi. Perbedaan ini disebabkan pada usahatani benih jagung ada tambahan kegiatan, yaitu roughing dan detaselling. Roughing merupakan teknik yang dilaksanakan dalam produksi benih untuk menjaga kemurnian varietas, dilaksanakan pada fase vegetatif umur 32-35 HST dan fase generatif umur 4552 HST (Syamsia, dkk., 2019). Yasin (2009) mengemukakan bahwa roughing dilakukan dengan membuang bagian tanaman yang menyimpang dari kondisi genotip tanaman. Panduan yang digunakan dalam roughing pada tanaman jagung adalah warna batang, warna daun, tinggi tongkol, tinggi batang, umur berbunga, warna rambut, warna malai yang menyimpang dan tanaman yang terinfeksi penyakit segera dibuang.

Detaseling atau pemangkasan bunga jantan pada barisan tanaman induk betina dilakukan sebelum bunga jantan terbuka atau muncul dari daun terakhir. Detaseling dilaksanakan dengan tujuan agar tidak terjadi penyerbukan sehingga energi yang berasal dari hasil fotosintesis yang digunakan untuk membentuk bunga jantan dialihkan untuk membentuk tongkol (Shodikin dan Wardiyati, 2017; Herlina dan Fitriani, 2017; Damanhuri, dkk., 2018). Teknik detaseling perlu dilakukan dengan tepat karena kesalahan pemangkasan bunga jantan dapat memberikan dampak negatif terhadap produksi jagung. Damanhuri, dkk. (2018) mengemukakan bahwa umur 50 HST merupakan saat yang tepat untuk memangkas bunga jantan karena pada umur tersebut pertumbuhan vegetatif tanaman telah berhenti. Pemotongan bunga jantan tidak mempunyai pengaruh yang nyata apabila dilakukan menjelang panen karena akumulasi hasil fotosintesa pada tanaman yang dipotong bunga jantannya kurang maksimal membentuk tongkol buah jagung. Nindita, dkk. (2017) melakukan pemotongan bunga jantan pada saat 12 hari sebelum panen dan tidak menunjukkan pengaruh yang nyata terhadap produksi jagung. 


\subsubsection{Biaya Usahatani}

Biaya usahatani jagung terdiri dari biaya pembelian sarana produksi dan upah tenaga kerja. Analisis biaya menggunakan biaya total, artinya semua biaya diperhitungkan meskipun secara riil petani tidak mengeluarkan biaya seperti upah tenaga kerja petani dan tenaga kerja dari dalam keluarga. Upah tenaga kerja keluarga disetarakan dengan nilai upah tenaga kerja luar keluarga yang berlaku di daerah penelitian. Biaya usahatani jagung secara keseluruhan disajikan pada Tabel 3. dari total biaya usahatani.

Proporsi biaya terbesar kedua adalah biaya pemupukan untuk membeli pupuk organik dan pupuk anorganik, yaitu sebesar Rp2.625.000,00 dan Rp2.469.500,00 atau 15,55 dan 23,13 persen dari total biaya usahatani benih jagung dan usahatani jagung konsumsi. Proporsi biaya terbesar selanjutnya adalah pembelian benih, masing-masing sebesar Rp1.170.000,00 (6,88 persen) dan $\operatorname{Rp} 1.147 .500,00$ (10,75 persen) dari biaya usahatani.

Tabel 3. Biaya per Hektare Usahatani Jagung di Desa Wirosari, Kecamatan Patean, Kabupaten Kendal, 2018

\begin{tabular}{|c|c|c|c|c|c|}
\hline \multirow{3}{*}{ No. } & \multirow{3}{*}{$\begin{array}{c}\text { Jenis Input } \\
\text { Produksi }\end{array}$} & \multicolumn{4}{|c|}{ Jenis Teknologi Usahatani } \\
\hline & & \multicolumn{2}{|c|}{ Benih Jagung } & \multicolumn{2}{|c|}{ Jagung Konsumsi } \\
\hline & & Nilai (Rp) & $\begin{array}{c}\% \text { dari Biaya } \\
\text { Total }\end{array}$ & Nilai (Rp) & $\begin{array}{c}\% \text { dari Biaya } \\
\text { Total }\end{array}$ \\
\hline \multirow{4}{*}{$\begin{array}{l}\mathrm{I} . \\
1 .\end{array}$} & Input produksi & & & & \\
\hline & Benih & & & 1.147 .500 & 10,74 \\
\hline & a. Tetua jantan & 750.000 & 4,41 & - & - \\
\hline & b. Tetua betina & 420.000 & 2,47 & - & - \\
\hline \multirow[t]{6}{*}{2.} & Pupuk & & & & \\
\hline & a. Urea & 665.000 & 3,91 & 693.500 & 6,50 \\
\hline & b. SP-36 & - & - & 220.000 & 2,06 \\
\hline & c. $\mathrm{KCl}$ & - & - & 360.000 & 3,37 \\
\hline & d. Phonska & 960.000 & 5,65 & 396.000 & 3,71 \\
\hline & e. Organik & 1.000 .000 & 5,89 & 800.000 & 7,49 \\
\hline 3. & Pestisida & 220.000 & 1,29 & 220.000 & 2,06 \\
\hline 4. & Plastik kemasan & 263.500 & 1,55 & - & - \\
\hline 5. & Sertifikasi benih & 232.500 & 1,37 & - & - \\
\hline \multirow[t]{2}{*}{ II. } & Upah tenaga kerja & 12.480 .000 & 73,45 & 6.840 .000 & 64,06 \\
\hline & Total biaya & 16.991 .000 & & 10.677 .000 & \\
\hline
\end{tabular}

Sumber: Data primer, 2018 (diolah)

Biaya terbesar pada usahatani jagung, baik usahatani benih jagung maupun usahatani jagung konsumsi terletak pada upah tenaga kerja masing-masing mencapai 73,45 persen dan 64,06 persen dari total biaya usahatani. Dewi, dkk. (2015) juga mendapatkan proporsi biaya upah tenaga kerja merupakan upah terbesar antara 49,99-71,67 persen dari total biaya usahatani, berbeda dengan penelitian Apriani, dkk. (2016) upah tenaga kerja menempati proporsi biaya terbesar kedua setelah biaya pembelian input produksi, yaitu 39,72 persen

\subsubsection{Produksi dan Keuntungan Usahatani Jagung}

Perbedaan teknologi usahatani antara usahatani benih jagung dengan usahatani jagung konsumsi memberikan perbedaan hasil dan keuntungan yang diterima petani seperti tersaji pada Tabel 4.

Dalam analisis kelayakan usahatani, faktor biaya dan penerimaan yang diperoleh dari nilai produksi yang dihasilkan merupakan hal penting untuk menentukan ekonomi suatu usahatani. Usahatani disebut layak atau menguntungkan 
Table 4. Kelayakan Usahatani Jagung di Desa Wirosari, Kecamatan Patean, Kabupaten Kendal, 2018

\begin{tabular}{|c|c|c|c|c|c|}
\hline \multirow{3}{*}{ No. } & \multirow{3}{*}{ Uraian } & \multicolumn{4}{|c|}{ Jenis Teknologi Usahatani } \\
\hline & & \multicolumn{2}{|c|}{ Benih Jagung } & \multicolumn{2}{|c|}{ Jagung Konsumsi } \\
\hline & & Fisik(kg) & Nilai (Rp) & Fisik (kg) & Nilai (Rp) \\
\hline \multirow[t]{4}{*}{1} & Produksi & & & & \\
\hline & a. Benih & 1550 & 54.250 .000 & - & - \\
\hline & b. Jagung konsumsi & 663 & 2.652 .000 & 6300 & 25.200 .000 \\
\hline & Jumlah Penerimaan & & 56.902 .000 & & 25.200 .000 \\
\hline 2 & Keuntungan & & 39.911 .000 & & 14.523 .000 \\
\hline 3. & BCR & & 2,35 & & 1,36 \\
\hline
\end{tabular}

Sumber: Data primer, 2018 (diolah)

jika nilai produksi yang dihasilkan melebihi semua biaya yang dikeluarkan oleh petani, artinya semua pengeluaran petani untuk melakukan aktivitas usahatani dapat diganti dari produksi yang dihasilkan dan petani masih mendapatkan sisa sebagai keuntungan atau pendapatan. Peningkatan pendapatan usahatani benih jagung merupakan salah satu pengungkit peningkatan pendapatan rumah tangga petani, jadi bukan merupakan satu-satunya sumber peningkatan pendapatan usahatani.

Produksi jagung yang diperoleh pada teknologi usahatani benih jagung sebanyak $1.550 \mathrm{~kg} / \mathrm{ha}$. Produksi benih yang diperoleh lebih tinggi 22,50 persen dibandingkan dengan ratarata benih yang diperoleh dari penelitian Sari, dkk. (2018) dengan mengaplikasikan beberapa kombinasi pupuk dan prebiotik, yaitu $1.265 \mathrm{~kg} /$ ha. Perbedaan hasil ini diduga karena perbedaan lokasi yang mempunyai karakteristik tersendiri. Untuk menunjukkan potensi hasil dari suatu varietas, maka varietas tersebut memerlukan kondisi lingkungan atau agroekosistem tertentu. Sebagaimana dikatakan oleh Suharno dan Rusdin (2017) bahwa produktivitas tanaman jagung ditentukan oleh faktor genetik dan lingkungan tempat tumbuh. Dengan demikian varietas jagung yang sama apabila ditanam di tempat yang berbeda maka produksi yang diperoleh juga akan berbeda. Demikian pula jika varietas yang berbeda ditanam di tempat yang sama akan memberikan hasil yang berbeda pula.

Selain memperoleh benih jagung, petani juga mendapatkan jagung konsumsi yang merupakan sortiran dari benih jagung. Produksi jagung konsumsi sebagai hasil samping usahatani benih jagung sebanyak $663 \mathrm{~kg}$ atau 42,77 persen dari total produksi benih jagung. Dengan tingkat harga Rp35.000,00/kg untuk benih jagung dan Rp4.000,00/kg untuk jagung konsumsi maka diperoleh nilai penerimaan secara keseluruhan sebesar Rp56.902.000,00/ ha. Setelah dikurangi biaya yang dikeluarkan oleh petani maka diperoleh keuntungan sebesar Rp39.911.000,00/ha. Dari analisis Benefit Cost Ratio (BCR) diketahui bahwa nilai BCR usahatani benih jagung sebesar 2,35 lebih tinggi dari nilai BCR usahatani jagung konsumsi yang hanya sebesar 1,36 , artinya keuntungan yang diperoleh petani dari usahatani benih jagung lebih besar dibandingkan keuntungan yang diperoleh petani dari usahatani jagung konsumsi. Meskipun nilai BCR berbeda, namun nilai tersebut mengindikasikan bahwa petani masih mendapatkan keuntungan dari masingmasing teknologi usahatani jagung.

\subsection{Perubahan Teknologi Usahatani dan Nisbah Peningkatan Keuntungan}

Proporsi biaya usahatani jagung untuk benih maupun untuk konsumsi terhadap penerimaan yang diperoleh cukup tinggi, yaitu masing-masing 29,86 persen dan 42,37 persen. Hal ini mengimplikasikan bahwa semakin besar proporsi biaya terhadap penerimaan maka keuntungan yang diterima petani semakin kecil. Meskipun biaya usahatani pada teknologi usahatani benih jagung secara nominal lebih besar, namun mempunyai proporsi biaya yang lebih rendah sehingga petani mendapatkan keuntungan yang lebih tinggi dibandingkan pada teknologi usahatani jagung konsumsi. Perbedaan keuntungan usahatani benih jagung dengan usahatani jagung konsumsi 
Tabel 5. Analisis Parsial Perubahan Teknologi Usahatani Jagung dari Teknologi Usahatani Jagung Konsumsi ke Teknologi Usahatani Benih Jagung di Desa Wirosari, Kecamatan Patean, Kabupaten Kendal, 2018

\begin{tabular}{clrrr}
\hline No. & Kerugian (Losses) & Jumlah (Rp) & Keuntungan (Gains) & Jumlah ( Rp) \\
\hline 1. & Tambahan biaya input & 674.000 & $\begin{array}{l}\text { Tambahan } \\
\text { penerimaan }\end{array}$ & 31.702 .000 \\
$\begin{array}{l}\text { produksi } \\
\text { 2. }\end{array}$ & 5.640 .000 & & \\
& kerja & & & \\
& Jumbahan upah tenaga & 6.314 .000 & & \\
& Tambahan keuntungan & 25.388 .000 & & \\
\hline MBCR & 4,02 & \\
\hline NKB & 2,75 & \\
\hline
\end{tabular}

Sumber: Data primer, 2018 (diolah)

sebesar Rp25.388.000,00. Hasil analisis parsial perubahan teknologi usahatani jagung disajikan pada Tabel 5.

Perubahan teknologi dari teknologi usahatani jagung konsumsi ke teknologi usahatani benih jagung memberikan nilai Marginal Benefit and Cost Ratio (MBCR) sebesar 4,02, artinya setiap tambahan biaya sebesar Rp100.000,00 memberikan tambahan keuntungan sebesar Rp402.000,00. Tambahan keuntungan yang diterima petani masih lebih besar dibandingkan dengan tambahan biaya usahatani sehingga teknologi usahatani benih jagung secara ekonomis dapat diterapkan petani. Meskipun usahatani benih jagung mengeluarkan biaya tambahan sebesar Rp6.314.000,00 namun petani mendapatkan tambahan keuntungan yang lebih besar, yaitu sebesar Rp25.388.000,00 Manfaat yang diperoleh petani dari perubahan teknologi diindikasikan dengan nilai $\mathrm{MBCR}=4,02$.

Nilai nisbah keuntungan bersih (NKB) dari teknologi usahatani benih jagung adalah 2,75. Hal ini mengindikasikan bahwa penerapan teknologi usahatani benih jagung mampu meningkatkan keuntungan bagi petani, diindikasikan dengan nilai NKB $>1$. Secara normatif, keuntungan usahatani benih benih jagung meningkat dari Rp14.143.000,00 menjadi Rp39.911.500,00 atau meningkat Rp25.388.500,00 (176,50 persen) dari keuntungan usahatani jagung konsumsi. Hasil ini menguatkan nilai MBCR 4,02 yang mengindikasikan perubahan teknologi usahatani dari teknologi usahatani jagung konsumsi ke teknologi usahatani benih jagung memberikan keuntungan yang layak bagi petani sehingga teknologi usahatani benih jagung dapat dikembangkan terutama di lokasi kegiatan.

\subsection{Analisis Titik Impas Produksi (TIP) dan Titik Impas Harga (TIH)}

Analisis titik impas produksi dan harga dalam usahatani jagung dilakukan untuk mengetahui hubungan yang terjadi antara biaya usahatani, harga benih jagung, harga jagung konsumsi dan volume hasil produksi. Titik impas produksi dan harga secara matematis merupakan titik perpotongan antara penerimaan dengan total biaya saat keuntungan yang diperoleh sama dengan nol. Perpotongan ini menggambarkan tingkat produksi dan harga minimal yang harus diterima petani untuk mengembalikan modal usahatani. Analisis titik impas produksi dan titik impas harga disajikan pada Tabel 6 .

Pada teknologi usahatani benih jagung diperoleh produksi sebesar $1.550 \mathrm{~kg}$ dan harga benih Rp35.000,00/kg diperoleh TIP sebesar $479 \mathrm{~kg}$ dan $\mathrm{TIH}$ sebesar Rp10.812,00/kg. Titik impas yang diperoleh mengindikasikan bahwa pada titik tersebut petani tidak mengalami kerugian. Batas toleransi penurunan produksi dan harga yang tidak menyebabkan kerugian adalah 69,10 persen dari produksi dan harga aktual, namun apabila penurunan produksi maupun harga lebih besar dari 69,10 persen dari produksi dan harga aktual, namun apabila penurunan produksi maupun harga lebih besar dari 69,10 persen petani mengalami kerugian.

Di sisi lain, teknologi usahatani jagung konsumsi mempunyai harga jagung pipilan kering sebesar Rp4.000,00/kg dan tingkat 
produksi yang dihasilkan $6.300 \mathrm{~kg}$ maka TIP $=2.669$ dan $\mathrm{TIH}=1.695$. Nilai yang diperoleh mengindikasikan bahwa apabila terjadi penurunan harga dari Rp4.000,00/kg menjadi $\mathrm{Rp} 1.695,00 / \mathrm{kg}$ dan produksi turun dari 6.300 $\mathrm{kg}$ menjadi $2.669 \mathrm{~kg}$ maka usahatani jagung konsumsi tidak menguntungkan dan tidak merugikan petani. Pada kondisi demikian petani berada pada titik impas produksi dan titik impas harga. Kedua titik impas yang diperoleh masih di bawah kondisi produksi dan harga aktual. Toleransi penurunan kedua titik impas tersebut relatif sama, yaitu sekitar 57,63 persen, artinya petani masih diuntungkan apabila produksi turun hingga 57,63 persen, demikian pula dengan batas penurunan harga yang masih bisa ditoleransi sebesar 57,63 persen dari harga aktual. Penurunan di atas kedua titik impas tersebut petani akan mengalami kerugian.

Hasil yang sama diperoleh dari penelitian Dewi, dkk. (2015) bahwa harga jagung Rp6.000,00/kg toleransi penurunan produksi dan harga pada jagung varietas Provit A1 adalah 67,34 persen dari produksi $7.100 \mathrm{~kg}$ dan Provit A2 66,39 persen dari produksi $6.900 \mathrm{~kg}$ dibandingkan varietas lokal Sigi dengan produksi $2.500 \mathrm{~kg}$ dengan batas penurunan 35,36 persen. Berdasarkan hasil-hasil penelitian tersebut menunjukkan bahwa teknologi usahatani yang mempunyai produksi dan harga jagung yang lebih tinggi mempunyai batas toleransi yang lebih luas dibandingkan produksi dan harga jagung yang lebih rendah.

\section{KESIMPULAN DAN SARAN}

Keuntungan usahatani benih jagung lebih tinggi dibandingkan keuntungan usahatani jagung konsumsi, yaitu Rp39.911.000,00/ha $(B C R=2,35)$ dibandingkan Rp14.523.000,00 $(B C R=1,36)$. Meskipun nilai $B C R$ berbeda, namun nilai tersebut mengindikasikan bahwa petani masih mendapatkan keuntungan dari masing-masing teknologi usahatani jagung.

Perbedaan biaya antara usahatani benih jagung dan jagung konsumsi sebesar Rp6.314.000,00. Namun dengan tambahan biaya tersebut petani mendapatkan tambahan keuntungan Rp25.388.000,00 diindikasikan dengan nilai $\mathrm{MBCR}=4,02$ dengan nisbah keuntungan bersih 2,75 persen.
Titik impas produksi dan harga pada usahatani benih jagung mempunyai batas toleransi penurunanyang lebih luas dibandingkan dengan usahatani jagung konsumsi, masingmasing sebesar 69,10 dan 57,63 persen. Oleh karena itu untuk meningkatkan produksi dan pendapatan petani jagung perlu adanya perluasan percontohan teknologi perbenihan jagung di beberapa sentra produksi jagung

\section{UCAPAN TERIMAKASIH}

Ucapan terimakasih disampaikan kepada Badan Penelitian dan Pengembangan Pertanian atas pembiayaan yang diberikan melalui DIPA BPTP Jawa Tengah TA 2018 pada kegiatan Pendampingan Kawasan Tanaman Jagung Melalui Introduksi Teknologi Produksi Perbenihan Jagung dengan Percontohan Inovasi. Ucapan terimakasih juga disampaikan kepada PPL Desa Wirosari, yaitu Samsudin dan Adikuncahyo atas peran sertanya dalam membantu pelaksanaan impelementasi teknologi perbenihan jagung dan pelaksanaan survei kepada petani yang memproduksi jagung konsumsi.

\section{DAFTAR PUSTAKA}

Amzeri, A. 2018. Tinjauan Perkembangan Pertanian Jagung di Madura dan Alternatif Pengolahan Menjadi Biomaterial. Jurnal IImiah Rakayasa. Vol. 11(1): 74-86.

Apriani, A.E., Soetoro dan M.N. Yusuf. 2016. Analisis Usahatani Jagung (Zea mays L.) (Studi Kasus di Desa Pancawangi Kecamatan Pancatengah, Kabupaten Tasikmalaya). Jurnal Agriinfo Galuh. Vol. 2(3): 145-150.

BPS Jawa Tengah. 2019. Provinsi Jawa Tengah Dalam Angka 2019. Badan Pusat Statistik Provinsi Jawa Tengah.

Damanhuri, S.V. Dianti, dan L.D. Soelaksini. 2018. Aplikasi Teknik Detaseling dan Rasio Pemupukan Fosfor dan Kalium terhadap Hasil panen Jagung. Agriprima, Journal of Applied Agricultural Sciences. Vol. 2(2): 144-153.

Dewi, M., N. Ismail dan Y. Langsa. 2015. Kelayakan Usahatani Perbenihan Jagung Komposit dengan Pendekatan PTT di Kabupaten Sigi. Prosiding Seminar Nasional Serealia:692-699.

Handoko, S dan M.T. Mulyadi. 2017. Uji Adaptasi Varietas Unggul Baru (VUB) Jagung Hibrida sebagai Upaya Pemanfaatan Lahan Suboptimal di Kabupaten Tanjung Jabung Timur Provinsi Jambi. Prosiding Seminar Nasional Lahan Suboptimal 2017: 669-674

Handoko, S., Andri. 2016. Analisis Usahatani Jagung Hibrida dan Komposit pada Lahan Pasang Surut. Prosiding Seminar Nasional Lahan Suboptimal 
2016: 369-376.

Herlina, N. dan W. Fitriani. 2017. Pengaruh Persentase Pemangkasan Daun dan Bunga Jantan terhadap Hasil Tanaman Jagung (Zea mays L.). Jurnal Biodjati. Vol. 2(2): 115-125

Hidayat, Y., Y. Saleh dan M.W. 2012. Kelayakan Usahatani Padi Varietas Unggul Baru Melalui PTT di Kabupaten Halmahera Tengah. Jurnal Penelitian Pertanian Tanaman Pangan. Vol. 31(3): 166-172.

Kurniati, D. 2012. Analisis Risiko Produksi dan FaktorFaktor yang Mempengaruhinya pada Usahatani Jagung (Zea mays L.) di Kecamatan Mempawah Hulu Kabupaten Landak. Jurnal Sosial Ekonomi Pertanian. Vol. 1(3): 60-68.

Margaretha, S. dan Syuryawati. 2017. Adopsi Teknologi Produksi Jagung dengan Pendekatan Pengelolaan Tanaman Terpadu pada Lahan Sawah Tadah Hujan. Jurnal Penelitian Pertanian Tanaman Pangan. Vol. 1(1): 53-63

Nindita, A.D., Koesriharti dan T. Islami. 2017. Pengaruh Pemotongan Bunga Jantan (Topping) dan Pupuk Kandang Sapi terhadap Pertumbuhan dan Hasil Tanaman Jagung (Zea mays var. saccarata). Jurnal Produksi Tanaman. Vol 5(9): $1554-1560$

Nugroho, W.S. 2015, Penetapan Standar Warna Daun sebagai Upaya Identifikasi Status Hara (N) Tanaman Jagung (Zea mays L.) pada Tanah Regosol. Planta Tropika: Journal of Agro Science. Vol. 3(1): 815.

Purwanto, A.Z.A., Hadayani dan A. Muis. 2015. Analisis Produksi dan Pendapatan Usahatani Jagung Hibrida di Desa Modo, Kecamatan Bukal, Kabupaten Buol. Jurnal Agroland. Vol. 22(3): 205-215.

Pusat Data dan Sistem Informasi Pertanian. 2018. Outlook Jagung Komoditas Pertanian Subsektor Tanaman Pangan. Kementerian Pertanian. 88p.

Pusparini, P.G., A. Yunus dan D. Harjoko. 2018. Dosis Pupuk NPK terhadap Pertumbuhan dan Hasil Jagung Hibrida. Agrosains. Vol. 20(2): 28-33

Rusdin, M.A. Mustaha dan Hilman. 2012. Analisis Finansial dan Titik Impas Usahatani Padi Melalui Pendekatan Pengelolaan Tanaman Terpadi di Sulawesi Tenggara. Jurnal Pengkajian dan Pengembangan Teknologi Pertanian. Vol. 15(1): 55-61

Sari, P.M., Surachman dan C. Budiman. 2018. Peningkatan Produksi dan Mutu Benih Jagung Hibrida melalui Aplikasi Pupuk N, P, K dan Bakteri Probiotik. Buletin Agrohorti. Vol. 6(3): 412-421

Sejati, W.K. 2015. Peranan Benih Unggul Jagung Hibrida dalam Peningkatan Produksi Pangan:
Studi Kasus di Kabupaten Klaten. Prosiding Seminar Nasional Swasembada Pangan.: 285292.

Shodikin, A dan Wardiyati. 2017. Pengaruh Defoliasi dan Detaseling terhadap Hasil Tanaman Jagung (Zea mays L.). Plantropika Journal of Agricultural Science. Vol. 2(1): 18-22.

Silva, H. dan Murdolelono. 2011. Analisis Kelayakan Ekonomi Usahatani Jagung Hibrida Bima I di Nusa Tenggara Timur. Prosiding Seminar Nasional Serealia: 642- 646.

Suharno dan Rusdin. 2017. Kelayakan Usahatani Jagung Hibrida di Kabupaten Muna Provinsi Sulawesi Tenggara. Jurnal Pengkajian dan Pengembangan Teknologi Pertanian. Vol. 29(1): 35-46.

Sulistiani. 2015. Analisis Usaha Tani Jagung (Zea mays) di Desa Kuwolu Kecamatan Bululawang Kabupaten Malang. Ziraa'ah. Vol. 40(3): 226231.

Syafruddin. 2016. Pemupukan N, P dan K Spesifik Lokasi pada Tanaman Jagung di Kabupaten Gowa Sulawesi Selatan. Jurnal Pengkajian dan Teknologi Pertanian. Vol. 19(2): 119- 133.

Syamsia, S., A. Idhan dan Kasifah. 2019. Produksi Benih Jagung Hibrida Menggunakan Sistem Tanam Tanpa Olah Tanah. Jurnal Dinamika Pengabdian. Vol. 5(1): 49-56.

Tahir, A.G. 2017. Analisis Pendapatan Usahatani Jagung pada Lahan Sawah dan Tegalan di Kecamatan Ulaweng, Kabupaten Bone, Sulawesi Selatan. Jurnal Galung Tropika. Vol. 6(1): 1-11

Wahyudin, A., Y. Yuwariyah, F.Y. Wicaksono dan R.A.G. Bajri. 2017. Respon Jagung (Zea mays L.) Akibat Jarak tanam pada Sistem Tanam Legowo (2:1) dan Berbagai Dosis Pupuk Nitrogen pada Tanah Inceptisol Jatinangor. Jurnal Kultivasi. Vol. 16(3): 507-513

Wahyuningsih, A., B.M. Setiawan dan B.A. Kristanto. 2018. Efisiensi Ekonomi Penggunaan FaktorFaktor Produksi, Pendapatan Usahatani Jagung Hibrida dan Jagung Lokal di Kecamatan Kemusu, Kabupaten Boyolali. Jurnal Agrisocionomics Sosial Ekonomi Pertanian. Vol.2(1): 1-13.

Yasin, M. 2009. Upaya Penyediaan Benih Dasar Jagung Komposit Melalui Pembinaan Penangkar Benih di Tingkat Petani. Prosiding Seminar Nasional Serealia:13-20. 


\section{BIODATA PENULIS:}

Dewi Sahara dilahirkan di Pati, 6 Desember 1968. Penulis menyelesaikan pendidikan S1 Budidaya Tanaman Universitas Hasanuddin Makassar lulus pada tahun 1992, dan melanjutkan Pascasarjana S2 Ekonomi Pertanian di Universitas Gadjah Mada Yogyakarta lulus tahun 2001 dan S3 Ekonomi Pertanian di IPB Bogor lulus tahun 2011.

Elly Kurniyati dilahirkan di Bogor, 13 September 1973. Penulis menyelesaikan S1 Sosial Ekonomi Pertanian Universitas Sebelas Maret tahun 1997.

Renie Oelviani dilahirkan di Jakarta, 30 Desember 1973. Penulis menyelesaikan pendidikan S1 Ekonomi Universitas Diponegoro Semarang tahun 1999 dan S2 Agribisnis Universitas Diponegoro Semarang pada tahun 2011.

Sodiq Jauhari dilahirkan di Semarang, 20 Oktober 1968. Penulis menyelesaikan pendidikan S1 Budidaya Tanaman Universitas Tidar Magelang pada tahun 1995. 